\title{
COMPARATIVE EXPRESSION OF SURFACE GLYCOCONJUGATES ACCORDING TO THE NORMAL OR INVASIVE PHENOTYPE OF THREE INTESTINAL EPITHELIAL CELL LINES
}

Patricia de Albuquerque Garcia Redondo*, Livia Goto-Silva, L*., Alan Nunes Moraes*, Celso Vataru Nakamura**, Wanderley de Souza*** and José Andres Morgado Díaz*

*Divisão de Biologia Celular, Coordenação de Pesquisa, Instituto Nacional de Câncer, Praça da Cruz Vermelha, $23 / 6^{\circ}$ andar, 20230-130, Rio de Janeiro/RJ.

** Laboratório de Microbiologia, Departamento de Análises Clínicas, UEM 87020-900, Maringá, PR.

${ }^{* * *}$ Laboratório de Ultraestrutura Celular Hertha Meyer, IBCCF - UFRJ, 21949-900, Rio de Janeiro, RJ.

Expression of surface glycoconjugates seem to be related to physiological processes that are influenced by the cellular glycocalix [1,2]. In cancer several studies have shown differential expression of cell surface glycoconjugates using fluorochromes-lectins, lectin-gold ultrastructural cytochemistry of serum of patients. However, the reported results which associate the process of transformation of a normal cell into a malign cell are often contradictory [3]. In the present study, we have performed a detailed analysis of the expression of glycoconjugates on the cell surface of normal and tumor epithelial cells and compared the expression of this molecules according to cellular differentiation state.

Cell monolayers of Caco-2, a well-differentiated adenocarcinoma cell line, IEC-6, a normal intestinal epithelial cell line and HCT-116, a very invasive and non differentiated adenocarcinoma cell line, were used. After 7 days of culture, the sugar residues on the cell surface were mapped using several lectins: UEA1 (Ulex europaeus), WGA (Triticum vulgaris), SNA (Sambucus nigra), HPA (Helix pomatia), BSI (Bandeira simplicifolia), WFH (Wisteria floribunda), PNA (Arachai hypogaea) and Con A (Concavalin A). By scanning resolution electron microscopy, cells were incubated in the presence of $10 \mathrm{~nm}$ colloidal gold-labelled lectins. After fixation and postfixation, the cells were dehydrated, critical point-dried in $\mathrm{CO}_{2}$, coated with carbon and examined in a Jeol JSM-6340F Field Emission Scanning Electron Microscope. Significative differences of carbohydrates residues expression on the cell surface between the three cell lines used were observed, particularly those recognized by WGA and HPA (N-acetyl D-gactosamine and $\mathrm{N}$-acetyl D-glucosamine residues) as seen in backscattered electrons imaging of its respectives secondary electron images (Figs 1A-F). The mapping of glycoconjugates was also performed by fluorescence using FITC or TRITCconjugated lectins, by the pre-embedding techniques using gold labeled probes and corroborated by western blotting using highly enriched membrane fractions of the cells and HRP-conjugated WGA and HPA lectins. Differences of labelling at the plasma membrane microvilli in relation to the smooth plasma region were also observed.

Our observations suggest that the differences in expression of glycoconjugates on the cell surface in these cell lines are associated with the malign transformation process as well as to the cellular differentiation state.

\section{References:}

[1] Kovbasnjunk, O., and Spring, K. R., 2000.The Journal of Membrane Biology. 176, 19-29.

[2] Gebert, A. et al, 2000. Cell Biology. 113, 389-399.

[3] Varki, A. et al,1997. FASEB Journal. 11, 248-255. 
Figure 1 - High resolution scanning electron microscopy of IEC-6 (A), CACO-2 (C) and HCT-116 cells (E) (secondary electron images). Corresponding backscattered electron images showing of the cells labelled with the WGA lectin, revealed using gold particles, which appear as light dots on the cell surfaces and microvilli (B,D,F).
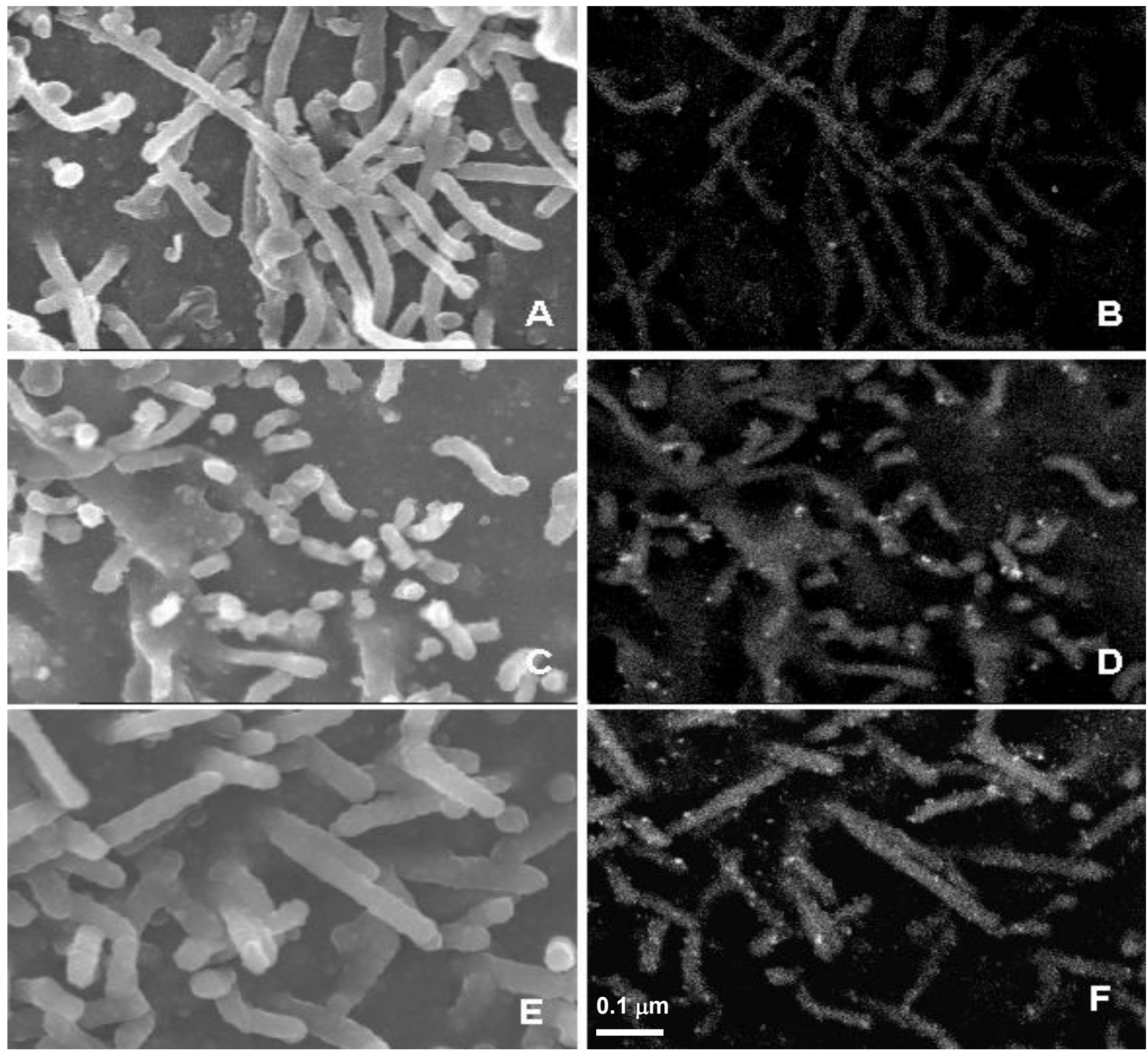